(20), 73-80 [in Ukrainian].

Tkachenko, A. V. (2011). Zavod elektroinstrumentiv dytiachoi trudovoi komuny imeni F.E. Dzerzhynskoho yak seredovyshche profesiinoho rozvytku osobystosti [Plant of power tools of the children's labor commune named after FE Dzerzhinsky as an environment of professional development of personality]. Pedahohika i psykholohiia prof. osvity - Pedagogy and psychology prof. Education, 6, 183-192 [in Ukrainian].

Charushyna, E. Y. (2006). Formyrovanye predpryymchyvosty u starsheklassnykov v uslovyiakh sotsyalno-эkonomycheskoho profylia obuchenyia: dys. ... kand. ped. Nauk: 13.00.02 [Formation of entrepreneurship in high school students in the socio-economic profile of education]. Kostroma [in Russian].

УДК 374.72:37.046 (560)

DOI: https://doi.org/10.35387/od.2(20).2021.211-218

Постригач Надія Олегівна -
докторка педагогічних наук,
старший дослідник, старша
наукова співробітниця відділу
зарубіжних систем педагогічної
освіти і освіти дорослих
Інституту педагогічної освіти і
освіти дорослих імені Івана
Зязюна НАПН України

ORCID iD: https://orcid.org/0000-0002-5433-2938

E-mail: unadya1@gmail.com

\begin{abstract}
Postryhach Nadiia - Doctor of Pedagogical Sciences, Senior Researcher at the Department of Foreign Systems of Pedagogical and Adult Education of the Ivan Ziaziun Institute of Pedagogical and Adult Education of the NAES of Ukraine
\end{abstract}

\title{
ДІЯЛЬНІСТЬ ЦЕНТРІВ БЕЗПЕРЕРВНОÏ ОСВІТИ У ТУРЕЧЧИНІ
}

Анотація. Здійснений контент-аналіз літературних джерел засвідчив, що вітчизняна система безперервної освіти $\epsilon$ інституційно роздрібненою, не має достатніх ознак системності, характеризується відсутністю надійних механізмів стимулювання й недостатньо забезпечена фрінансово. Це зумовлює актуальність дослідження зарубіжного досвіду реалізації системи безперервної освіти, зокрема в Туреччині, що зумовлена потребою розширення їі доступності для всіх верств населення через створення центрів безперервної освіти при університетах.

Автор статті аналізуе особливості діяльності центрів безперервної освіти у Туреччині на базі університетів. Виявлено, що такі центри, спрямовані на досягнення локального розвитку, встановлюють зв'язки між університетами, виробниками знань, ринком та користувачами знань.

З'ясовано, що цільовою групою для реалізації освітньої діяльності центрів безперервної освіти є переважно особи з певним браком освіти, працівники без формальних кваліфрікацій, працівники-іммігранти та сільські 
працівники, які емігрували до міст. Доведено, що забезпечення центрами безперервної освіти тісного взаємозв'язку університетів $і$ громади; демократичність управління, а саме: визначення освітніх програм для усіх верств суспільства з урахуванням різних точок зору для з'ясування освітніх потреб, дотримання принципу безперервної освіти для кожного, забезпечення гнучкості освітніх програм, реалізація програм профресійного розвитку на запит компаній чи організацій для їхніх співробітників тощо, $\epsilon$ перспективними напрямами розвитку безперервної освіти в Україні.

Ключові слова: освіта дорослих; безперервна освіта; иентр безперервної освіти; навчання упродовж усього життя; неформальна освіта; Туреччина.

\section{Postryhach Nadiia}

\section{ACTIVITIES OF THE CONTINUING EDUCATION CENTERS IN TURKEY}

Abstract. The conducted content analysis of literature sources showed that the domestic system of continuing education is institutionally fragmented, does not have sufficient signs of systemicity, is characterized by the lack of reliable incentive mechanisms and is insufficiently provided financially. The relevance of the foreign experience studies in the implementation of the system of continuing education, in particular, in Turkey, is due to the need to expand its accessibility to all segments of the population through the creation of centers of continuing education at universities.

The author of the article analyzes the peculiarities of the activities of Turkish continuing education centers on the basis of universities. It was found that such centers, aimed at achieving local development, establish links between universities, producers of knowledge, the market and users of knowledge.

It was found that the target group for the implementation of educational activities of continuing education centers are mainly people with a certain lack of education, workers without formal qualifications, immigrant workers and rural workers who have emigrated to the cities. It is proved that the continuing education centers provides a close relationship between universities and society; democratic governance, namely: definition of educational programs for all segments of society taking into account different points of view to clarify educational needs, observance of the principle of continuing education for everyone, ensuring flexibility of educational programs, implementation of professional development programs at the request of companies or organizations are promising areas development of continuing education in Ukraine.

Key words: adult education; continuing education; continuing education center; lifelong learning; non-formal education; Turkey.

Постановка проблеми, її актуальність. Освіта впродовж життя є загальновизнаною необхідністю, яку Європейський Союз розглядає як важливий елемент соціальної моделі сучасного суспільства (Лук'янова, C. 1).

Безперервна освіта відіграє ключову роль у розвитку людського капіталу та економічному зростанні країни через ії̈ здатність фрормувати 
інтелектуальну складову в системі елементів економіки знань, поліпшувати здобутки людей, нації та суспільства щоденно в міру набуття й втілення в життя нових знань. Вивчення наукових джерел, сучасної практики реалізації безперервної освіти та ії нормативно-правового регламентування в Україні показало, що сьогодні вітчизняна система безперервної освіти $є$ інституційно роздрібненою, не має достатніх ознак системності, характеризується відсутністю надійних механізмів стимулювання й недостатньо забезпечена фінансово (Кашуба, 2011, с. 43).

Це зумовлює актуальність дослідження зарубіжного досвіду реалізації системи безперервної освіти, зокрема в Туреччині, з позиції розширення ії доступності для всіх верств населення через створення центрів безперервної освіти при університетах. Зазначимо, що останнім часом у Туреччині спостерігається зростання кількості освітніх програм у цій галузі через програму гармонізації $€$ з згідно з Концепцією освіти упродовж усього життя, яка має на меті вдосконалити базову систему забезпечення освіти дорослих, а також працювати над створенням ефрективнішої технічної та економічної інфрраструктури. Освітні програми зосереджені насамперед на «доброму» громадянстві й особистісному розвитку, а також на працевлаштуванні та розвитку навичок для промисловості (European Association, 2011, с. 4).

У Туреччині $\epsilon$ багато банків, приватних організацій і міністерств, які надають освітні послуги у власних центрах освіти дорослих для персоналу своїх організацій як цільовій категорії дорослих. Ця освіта зазвичай здійснюється у формі підвищення кваліфікації або відповідно до цілей подальшої освіти для розширення бази знань. Тобто ця освіта має такі цілі, як допомога персоналу працювати у злагоді з працівниками інших установ, оновлення професійних знань персоналу відповідно до інституційних цілей з метою підвищення ефективності його роботи, надання нової інформації, яка дозволить персоналу просуватися на вищі посади та досягати успіху на цих посадах, покращуючи відносини працівників із клієнтами, а також навички щодо просування продуктів і послуг (Ultanir, G., Ültanir, E., 2012, с. 92-100).

Аналіз актуальних досліджень і публікацій. Розвиток центрів освіти дорослих як складової неформальної освіти $є$ освітнім трендом у переважній більшості країн світу. Доцільність їх створення передусім зумовлюється нагальною необхідністю розширення сфрери освітніх послуг для різних категорій дорослого населення. Центри освіти дорослих (далі ЦОД) передусім $€$ осередками соціальної інтеграції громадян, які допомагають опановувати нові соціальні ролі, сприяють духовному зростанню, самоосвіті й самовихованню особистості (Аніщенко, 2018, с. 2425).

Європейська комісія визначає концепцію безперервної освіти, яка $€$ новим терміном для Туреччини, так: «усі освітні заходи, що здійснюються через усе життя з індивідуальним, соціальним, інституційним або працевлаштуванням, орієнтованим на вдосконалення знань, навичок та компетентностей». Відповідно до цього визначення, університети Англії, 
наприклад, заохочуються до розвитку безперервної освіти для досягнення цілей уряду за допомогою програм, спрямованих на збільшення державної підтримки вищої освіти та підготовки висококваліфікованої робочої сили. Водночас фінська модель $€$ відносно особливою для безперервної освіти. У Фінляндії центри безперервної освіти відіграють важливу роль у підтримці взаємодії між університетами та громадськістю. Їх діяльність спрямовано на досягнення локального розвитку. Такі центри встановлюють зв'язки між університетами, «виробниками знань», ринком і користувачами знань (Arslan, 2008, с. 145). Однак, українськими ученими не здійснюються комплексні дослідження, присвячені діяльності центрів безперервної освіти при університетах, що і зумовило вибір теми публікації.

Мета статті - проаналізувати особливості діяльності центрів безперервної освіти у Туреччині, що функціонують на базі університетів.

Виклад основного матеріалу дослідження. Навчання впродовж життя в Туреччині можна поділити на два періоди: дореспубліканський і постреспубліканський. У дореспубліканський період мечеті, секти, медресе, яничарські центри, організації ахі, гільдії й палацові школи були установами освіти дорослих для навчання впродовж життя. Після утвердження Республіки в 1923 р. народні школи (Halk Mektepleri), народні будинки (Halk Evleri) та нічні класи (Gece Dersleri) стали очевидними інституціями в освіті мас (Okçabol, 2006). Ще одним важливим освітнім рухом в історії Туреччини $\epsilon$ сільські інститути, створені з метою підготовки вчителів для роботи в селах (Okçabol, 2005). На початку функціонування нової республіки вчителі, котрі закінчили ці інститути, відігравали важливу роль у народній освіті. Забезпечення єдності національної культури, сприяння громадянській освіті та підготовка робочої сили були цілями освіти дорослих у ті часи. Освіта дорослих стала більш інституціоналізованою галуззю після 1960 р., із моменту створення Генерального директорату народної освіти (Halk Eğitim Genel Müdürlüğü), який згодом, у 1983 р., був перетворений на Головне управління 3 учнівства та неформальної освіти (Çıraklık ve Yaygın Eğitim Genel Müdürlüğü), що несе відповідальність за галузь освіти дорослих.

Концепція навчання впродовж усього життя стала феноменом для турецького суспільства починаючи з 1980 р. (Şimşek, 2008). 32011 p. діяльність з навчання впродовж усього життя здійснюється під дахом Генерального директорату з навчання впродовж усього життя (MEB, 2011), а проєкт, котрий реалізується під гаслом «школи оживають», відображає сучасний менталітет навчання впродовж усього життя в сучасній Туреччині. Не тільки Міністерство національної освіти, а й деякі інші установи, такі як міністерства юстиції, охорони здоров'я та оборони, займаються питаннями освіти дорослих (Okçabol, 2006; Kabahasanoğlu, 2002). У сучасній Туреччині навчання впродовж усього життя забезпечують як офріційні, так і приватні установи. Зокрема, турецькі університети у власній структурі створили центри безперервної освіти (ЦБО), що відповідальні за освіту мас і намагаються розвивати програми 3 урахуванням потреб окремих людей та економіки. У цьому контексті майже 
в кожному університеті функціонують ЦБО, що зосереджують діяльність на програмах саморозвитку, соціальної реалізації та професійної освіти. Більшість програм стосується використання комп'ютера й вивчення іноземних мов через аналіз поточних потреб суспільства.

Перший ЦБО був створений у 1991 р. на базі Близькосхідного технічного університету (Middle East Technical University, METU), і кількість таких центрів зростає разом із потребою в навчанні впродовж усього життя. $€$ певні критерії щодо створення ЦБО, одним із яких $€$ їх вагомий внесок у суспільство, зокрема забезпечення тісного взаємозв'язку університетів і громади, та в підсумку поліпшення якості життя людини. ЦБО мають переваги й для персоналу. Відділення й фракультети університетів можуть створювати професії; залучення до забезпечення безперервної освіти дає змогу академічному персоналу налагодити тісні зв'язки із власними професіями. Правовим підґрунтям ЦБО (SEM) у Туреччині $є$ Закон про вищу освіту (№ 2547-7/d). Однак слід зазначити, що $€$ не так багато законів, нормативних актів чи політичних документів, котрі безпосередньо пов'язані з навчанням упродовж усього життя. Разом із тим, $\epsilon$ правові документи, опосередковано пов'язані з навчанням упродовж усього життя. Це Основний закон № 1739 про національну освіту, Плани розвитку, Національні освітні ради (National Education Councils) та Альтернативні національні ради освіти (Alternative National Education Councils) (Akçay, 2014, c. 1758-1759).

Цільовою групою для реалізації освітньої діяльності ЦБО $є$ переважно особи з певним браком освіти, працівники без формальних кваліфікацій, працівники-іммігранти та сільські працівники, які емігрували до міст (European Association, с. 7).

Програми, що підтримуються ЦБО, об'єднані у три основні категорії. Загалом найпопулярнішими програмами навчання впродовж усього життя $€$ курси саморозвитку, особливо музичні курси, курси професійного розвитку та професійного навчання. Програми професійного розвитку переважно реалізуються на запит компаній чи організацій для своїх співробітників. Пошук різних типів професійного розвитку та профресійних програм можливий у будь-який час. Немає суттєвої різниці між статями для відвідування таких програм: і чоловіки, і жінки відвідують курси відповідно до своїх інтересів (Akçау, 2014, с. 1761).

Зазначимо, що ЦБО здебільшого організовують діяльність для суспільства у сферах, які набули значення для вдосконалення особистості, задля кар'єри, вдосконалення професійних знань і кваліфікацій, набуття нових навичок та забезпечення потреб індивідуального розвитку. Такі центри створені в університетах за принципом забезпечення безперервної освіти, доступної для всіх, із метою забезпечення навчання впродовж усього життя. ЦБО впроваджують більш гнучкі програми порівняно з тими, які реалізуються в інших 3ВО. Вони мають власні веб-сторінки та створені при державних і народних університетах Туреччини. Загальна кількість таких центрів становить 43, 3 них 34 у державних і 9 - приватних університетах. 
ЦБО мають дуже схожі засадничі принципи й організаційні структури та функціонують під управлінням ректорату конкретного університету під такими назвами, як «центр безперервної освіти» (continuing education center), «центр дослідження та застосування безперервної освіти» (continuing education research and application center), «центр навчання впродовж усього життя» (lifelong learning center), «центр досліджень та застосування підприємництва» (entrepreneurship research and application center), «центр інфрорматики безперервної освіти» (continuing education center of informatics) і «центр безперервної освіти та розвитку програм» (continuing education and program development center). 3 одного боку, наявність різних назв ЦБО викликає в певних людей проблеми зі сприйняттям, а з другого - додає центрам оригінальності.

До більшості адміністративних структур ЦБО входять директор, рада директорів і консультативна рада. Наявність останньої робить ці центри демократичнішими в управлінні, що дає їм змогу пропонувати різні види освітніх програм на благо суспільства. Оскільки потреби в освіті людей різноманітні, визначення змісту освітніх програм для всіх верств суспільства потребує врахування різних точок зору. Турецькі вчені з'ясували, що більшість ЦБО не згадують у своїх нормативних актах безпосередньо термін «навчання впродовж усього життя», i його відсутність $€$ істотним недоліком (Akçay, 2014, с. 1761; Arslan, 2008, с. 138139).

Наприклад, основною метою Центру прикладних і наукових досліджень безперервної освіти Ускюдарського університету (Üsküdar University Continuing Education Application and Research Center) $є$ зробити правильну інфрормацію найбільш зрозумілою та застосовною, отримати новий дизайн, зробити наявні знання доступними та відкрити нові вікна можливостей у житті людей з принципом безперервності в освіті, змінах та розвитку. У цьому відношенні основна місія Центру полягає в тому, щоб надати можливість людям більш активно використовувати свої здібності та навички, якими вони володіли, а також створити можливість вчитися, переживати та застосовувати на практиці знання, якими вони ще не володіють. Сферою діяльності Центру $є$ реалізація наступних стратегій навчання: 1) академічна та професійна підготовка; 2) корпоративне навчання; 3) відкриті тренінги загальної участі; 4) проекти соціальної відповідальності тощо (ÜSEM).

3 метою координації зусиль університетів, зацікавлених сторін та уряду у реалізації безперервної освіти 17 грудня 2010 р. було створено Раду Центрів безперервної освіти турецьких університетів (The Council of Turkish Universities Continuing Education Centers; Turkiye Universiteleri Surekli Egitim Merkezleri, TÜSEM). Наразі Рада TÜSEM налічує понад 100 членів. Фокусом пильної уваги Ради Центрів безперервної освіти турецьких університетів $є: 1)$ акредитація, оцінка, документація та інструктаж для всіх навчальних програм, організованих цими центрами; 2) забезпечення саморозвитку ЦБО як більш активних, поширених та кваліфікованих освітніх закладів, а також співпраці 3 різними національними та 
міжнародними інститутами й організаціями; 3) забезпечення сильного та централізованого представництва ЦБО перед органами влади; 4) сприяння вирішенню їх фрінансових та бюрократичних проблем; 5) внесення пропозицій щодо спільних проектів; 6) виступати в якості координатора спільних навчальних програм (TÜSEM, 2015).

Висновки і перспективи подальших досліджень. Таким чином, забезпечення ЦБО тісного взаємозв'язку університетів і громади; демократичність управління, а саме: визначення освітніх програм для усіх верств суспільства з урахуванням різних точок зору для з'ясування освітніх потреб, дотримання принципу безперервної освіти для кожного, забезпечення гнучкості освітніх програм, реалізація програм професійного розвитку на запит компаній чи організацій для їхніх співробітників тощо, $є$ перспективними напрямами розвитку безперервної освіти в Україні.

\section{Список використаних джерел}

Аніщенко, О.В. (2018). Моделі центрів освіти дорослих в Україні. Освіта дорослих: теорія, досвід, перспективи, 1 (14), 22-35. URL: http://www.adult-education-journal.com.ua/index.php/aej/issue/view/14/14.

Кашуба, О. М. (2011). Зарубіжний досвід реалізації системи безперервної освіти та перспективи його впровадження в Україні. Інвестиції: практика та досвід, 10, 43-48.

Лук'янова, Л. Неформальна освіта дорослих як невід'ємна складова освіти впродовж життя. URL: http://www.uaod.org.ua/data/ PRO_OSVITU_DOROSLYH/unformal_OD.PDF

European Association for the education on adults. (2011). Country Report on Adult Education in Turkey. Helsinki, $9 \mathrm{p}$. URL: https://eaea.org/wpcontent/uploads/2018/01/turkey_country-report-on-adult-education-inturkey.pdf

Akçay, R. C., \& Yıldırım, R. (2014). Evaluating the continuing education centers in terms of lifelong learning. 5th World Conference on Educational Sciences, 2013. Procedia - Social and Behavioral Sciences,116, 1756-1762.

Arslan, M. M. (2008). Structure and Functions of the Continuing Education Centers at Turkish Universities. Turkish Online Journal of Distance Education, 9 (3), art. 12, 138-148. URL: https://files.eric.ed.gov/fulltext/ED502089.pdf

TÜSEM: The Council of Turkish Universities Continuing Education Centers. (2015). Eucen: European University Continuing Education Network. URL: http://www.eucen.eu/images/network-profiles/tusem_profilev11-8.pdf

Ultanir, G., Ültanir, E. (2012). New Structures in Public Education Centers in Turkey. Problems of education in the 21st century, 44, 92-100. URL: http://oaji.net/articles/2014/457-1413726977.pdf

ÜSEM: Üsküdar University Continuing Education Application and Research Center. URL: https://uskudar.edu.tr/en/usem

\section{References (translated and transliterated)}

Anishhenko, O. V. (2018). Modeli centriv osvity` dorosly`x v Ukrayini [Models of adult education centers in Ukraine]. Osvita dorosly'x: teoriya, dosvid, perspekty'vy - Adult education: theory, experience, prospects, 1 (14), 22- 
35.

URL: http://www.adult-educationjournal.com.ua/index.php/aej/issue/view/14/14 [In Ukrainian].

Kashuba, O. M. (2011). Zarubizhny`j dosvid realizaciyi sy`stemy` bezperervnoyi osvity ta perspekty 'vy jogo vprovadzhennya v Ukrayini [Foreign experience in the implementation of the system of continuing education and prospects for its implementation in Ukraine]. Investy ciyi: prakty `ka ta dosvid - Investments: practice and experience, 10, 43-48 [In Ukrainian].

Luk'yanova, L. Neformal'na osvita dorosly`x yak nevid'yemna skladova osvity vprodovzh zhy`ttya [Non-formal adult education as an integral part of lifelong learning]. URL: http://www.uaod.org.ua/ data/PRO_OSVITU_DOROSLYH/unformal_OD.PDF [In Ukrainian].

European Association for the education on adults. (2011). Country Report on Adult Education in Turkey. Helsinki, 9. URL: https://eaea.org/wpcontent/uploads/2018/01/turkey_country-report-on-adult-education-inturkey.pdf [In English].

Akçay, R. C., \& Yıldırım, R. (2014). Evaluating the continuing education centers in terms of lifelong learning. 5th World Conference on Educational Sciences, 2013. Procedia - Social and Behavioral Sciences, 116, 1756-1762 [In English].

Arslan, M. M. (2008). Structure and Functions of the Continuing Education Centers at Turkish Universities. Turkish Online Journal of Distance Education, 9 (3), art. 12, 138-148. URL: https://files.eric.ed.gov/fulltext/ED502089.pdf [In English].

TÜSEM: The Council of Turkish Universities Continuing Education Centers (2015). Eucen: European University Continuing Education Network. URL: http://www.eucen.eu/images/network-profiles/tusem_profilev11-8.pdf [In English].

Ultanir, G., \& Ültanir, E. (2012). New Structures in Public Education Centers in Turkey. Problems of education in the 21st century, 44, 92-100. URL: http://oaji.net/articles/2014/457-1413726977.pdf [In English].

ÜSEM: Üsküdar University Continuing Education Application and Research Center. URL: https://uskudar.edu.tr/en/usem [In English]. 